\title{
DOSE DEPENDENT VARIATIONS OF CARRIER RECOMBINATION IN SILICON IRRADIATED BY HIGH ENERGY ELECTRONS *
}

\author{
E. Gaubas ${ }^{\mathrm{a}}$, A. Uleckas ${ }^{\mathrm{a}}$, and J. Višniakov ${ }^{\mathrm{b}}$ \\ ${ }^{a}$ Institute of Materials Science and Applied Research, Vilnius University, Sauletekio 10, LT-10223 Vilnius, Lithuania \\ E-mail: eugenijus.gaubas@ff.vu.lt \\ b Joint Stock Company "Vilniaus Ventos Puslaidininkiai”, Ateities 10, LT-08303 Vilnius, Lithuania
}

Received 9 July 2007; revised 14 September 2007; accepted 21 November 2007

\begin{abstract}
Carrier recombination and trapping characteristics are examined in electron irradiated float zone (FZ) grown Si diode structures. The samples have been irradiated with high energy (5-10 MeV) electrons, doses varying in the range of $0.1-$ 2 MRad. Activation energy of the trapping centres attributed to radiation defects is extracted from the lifetime variations with temperature. The vacancy related defects are identified by combining microwave probed photoconductivity transients (MW-PCT) and capacitance deep level transient spectroscopy (DLTS) data.
\end{abstract}

Keywords: carrier lifetime, FZ Si diodes, electron irradiation induced defects

PACS: $61.72 . J i, 61.82 . \mathrm{Fk}, 72.40 .+\mathrm{w}$

\section{Introduction}

Radiation technologies are exploited to increase switching rate in the case of high speed high voltage industrial devices. High densities of radiation induced defects [1] in high purity initial material restrict implementation of the classical characterization techniques, such as capacitance deep level transient spectroscopy (DLTS) and thermally stimulated currents (TSC) [2]. Therefore, the straightforward methods of carrier lifetime control are the most proper for characterization of irradiated material. The transient microwave (MW) probe technique is demonstrated [3] to be sufficiently sensitive to trace the carrier lifetime variations with fluence as well as to evaluate individual features of the recombination defects. In this work, the parameters of the vacancy related defects have been determined from temperature variations of the trapping constituent within excess carrier decay transients.

\section{Samples investigated}

Silicon diodes fabricated as CERN standard particle pad-detectors and commercially produced devices have been investigated. Processed device structures were irradiated by electrons of 5 and $10 \mathrm{MeV}$ energy. CERN

\footnotetext{
* The report presented at the 37th Lithuanian National Physics Conference, 11-13 June 2007, Vilnius, Lithuania.
}

standard detectors were irradiated by $5 \mathrm{MeV}$ electrons with dose of 1.1 MRad. CERN standard detectors contain metal uncovered optical window for complementary measurements. Commercial diodes made by Vilniaus Ventos Puslaidininkiai have been examined by using cross-sectional lifetime scans within diode boundary exploiting contactless techniques. These diodes were irradiated by $10 \mathrm{MeV}$ electrons varying the irradiation dose in the range of 0.1-2.2 Mrad.

\section{Experimental techniques}

Carrier decay transients are measured by non-invasive technique based on microwave absorption by free carriers [4]. Excess carriers are generated by exploiting $500 \mathrm{ps}$ IR $(1062 \mathrm{~nm})$ laser pulses and processes of their density relaxation are probed with $22 \mathrm{GHz}$ MW radiation. MW probed photoconductivity (MW-PCT) response is registered by Tektronix TDS-5104 oscilloscope. The transient components and relaxation rates are examined to identify the carrier recombinationtrapping processes and to extract the particular lifetimes. To determine the trap activation factors, variations of carrier lifetimes in wide range (90-450 K) of temperatures are investigated. DLTS measurements together with lifetime studies have been performed to identify carrier trapping centres. DLTS spectra have been recorded by employing a commercial 
spectrometer DLS-82E. These centres are ascribed to peaks within the lifetime dependences on temperature, examined by MW-PCT.

\section{Theoretical approaches for evaluation of parameters of trapping centres}

Recombination acting together with multi-trapping can be described by the instantaneous decay lifetime $\tau_{\text {in }}[5]$

$$
\tau_{\text {in }}=\tau_{\mathrm{R}} K_{\mathrm{tr}}
$$

whereby the recombination lifetime $\tau_{\mathrm{R}}$ is increased due to additional trapping / generation processes, estimated by a trapping coefficient $K_{\text {tr }}$ :

$$
K_{\mathrm{tr}}=1+\frac{M N_{\mathrm{C} M}}{\left(N_{\mathrm{C} M}+n_{0}+n_{\mathrm{ex}}\right)^{2}} .
$$

It is assumed that the observed hyperbolic-like decay at low excitation level is due to trapping by the centres of asymmetric cross-sections with a concentration $M$. The density of final states available for thermal generation of carriers in statistics of multi-trapping is a density of states in the conduction $\left(N_{\mathrm{C}}\right)$ or valence $\left(N_{\mathrm{V}}\right)$ band reduced by thermal factor of the trap activation, $N_{\mathrm{C}, \mathrm{V} M}=N_{\mathrm{C}, \mathrm{V}} \exp \left[-\left|E_{\mathrm{C}, \mathrm{V}}-E_{M}\right| /(k T)\right]$, respectively $[4,5] . \quad N_{\mathrm{C}, \mathrm{V} M}$ depends on energy depth $\left|E_{\mathrm{C}, \mathrm{V}}-E_{M}\right|$ of the trap level $E_{M}$ for thermal emission at temperature $T$ and $k$ is the Boltzmann constant. $n_{0}$ denotes the equilibrium carrier concentration and $n_{\mathrm{ex}}$ is the light induced excess carrier density. In order to separate the pure recombination characterized by $\tau_{R}$, the capture into a trapping level should be suppressed by increasing $n_{\mathrm{ex}}$, thus making the term $N_{\mathrm{C} M} M / n_{\mathrm{ex}}^{2}$ much smaller than 1 . Thus, carrier recombination and trapping constituents can be evaluated by examining the shape of excess carrier density relaxation and estimating their rates.

Formation of lifetime peaks in its temperature variation can be simulated by using the model described by Eqs. (1), (2) and illustrated in Fig. 1. The low temperature peak appears due to temperature dependent $N_{\mathrm{C} M}$ (Fig. 1). The trapping coefficient increases with $k T$ as $K_{\mathrm{tr}} \propto M N_{\mathrm{C} M} / n_{\mathrm{ex}}^{2} \propto \exp \left[-\Delta E_{M} /(k T)\right]$ if $N_{\mathrm{C} M}<n_{\mathrm{ex}}$ (a low temperature wing), and decreases with enhancement of $k T$ as $K_{\operatorname{tr}} \propto M / N_{\mathrm{C} M} \propto$ $\exp \left[\Delta E_{M} /(k T)\right]$ when $N_{\mathrm{C} M}>n_{\text {ex }}$ (a high temperature wing). In the low temperature range $\tau_{\mathrm{R}}$ is nearly invariable, thus, $\tau_{\text {in }}$ within the decay asymptote represents the $K_{\text {tr }}$ as a function of $\Delta E_{M} /(k T)$. Roughly, slopes of trapping peak of both wings are symmetrical

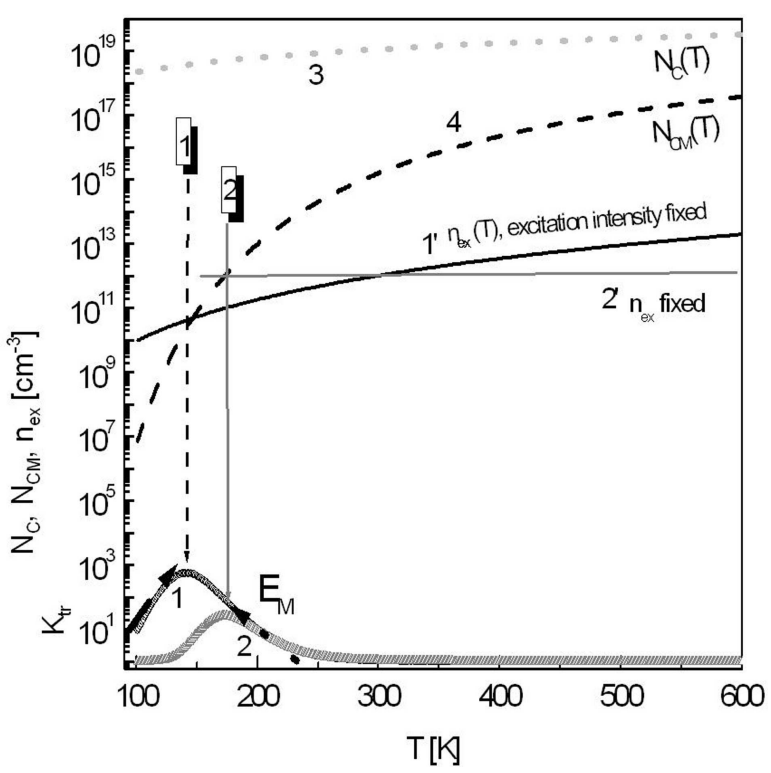

Fig. 1. Simulated formation of a lifetime peak (curves 1 and 2) within instantaneous lifetime $\tau_{\text {in }}$ temperature $(T)$ dependence due to trapping by centres with activation energy of $E_{M}=0.23 \mathrm{eV}$. Curve 1 corresponds to simulated $\tau_{\text {in }}(T)$ variation when excess carrier density $n_{\text {ex }}$ varies with temperature (at fixed excitation intensity) while dependence 2 is obtained at constant $n_{\mathrm{ex}}$, maintained by adjusting excitation intensity. Parameters of trapping centres can be extracted by employing asymptotic constituent of decays and slopes in the vicinity of a peak. Curves 1', 2' and 3, 4 show complementary functions of the excess carrier density at fixed ( 1 ') or varied (2') excitation intensity and of the effective, $N_{\mathrm{C}}(T)(3)$ and $N_{\mathrm{C} M}(T)$ (4), densities of states incorporated in simulations.

as approximately $\exp \left[ \pm \Delta E_{M} /(k T)\right]$. Values of $K_{\mathrm{tr}}$ depend on $M$ and $n_{\text {ex }}$. The trapping effect is resolvable if $K_{\mathrm{tr}} \gg 1$. It determines the temperature range of the peak formation. A peak amplitude is mainly determined by concentration of defects $M$, thus the excitation should be low enough. Then, an increase of $K_{\mathrm{tr}}$ is observable in the low temperature wing with decrease of $N_{\mathrm{C} M}$ and $n_{\mathrm{ex}}$. The latter $n_{\mathrm{ex}}$ falls with temperature at fixed excitation intensity due to a decrease of the inter-band absorption coefficient.

\section{Recombination and trapping lifetime variations with temperature}

The two-componential excess carrier decay transients have been observed in the electron irradiated FZ Si detectors in the low temperature range. The initial component of excess carrier density relaxation shows recombination lifetime increase with temperature (Fig. 2). The temperature dependent variations of the asymptotic constituent represent the trapping processes and exhibit three lifetime peaks (Fig. 2). These peaks correlate well with temperature ranges of the 


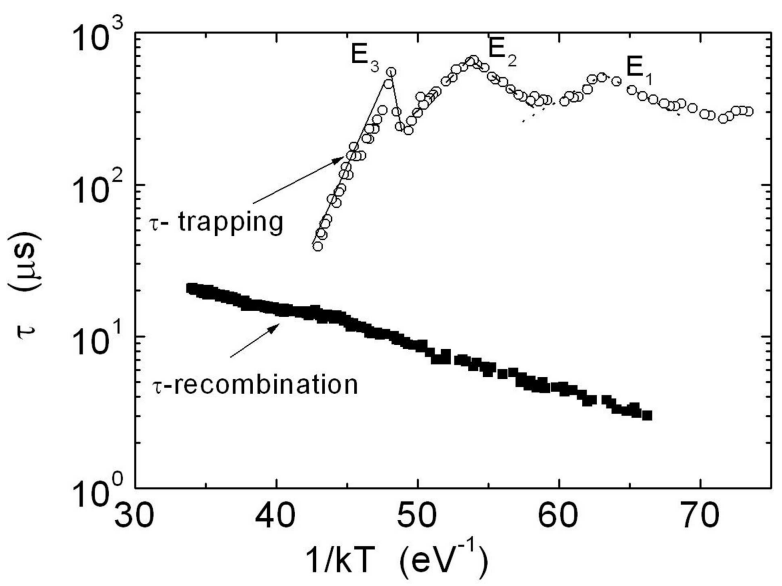

Fig. 2. Variations of recombination and trapping lifetime with temperature in $5 \mathrm{MeV}$ electron irradiated FZ Si diode using fluence of $3 \cdot 10^{12}$ electron $/ \mathrm{cm}^{2}$. Peaks in trapping lifetime variation can be attributed to radiation induced vacancy-oxygen (V-O with $E_{1} \sim$ $0.16 \mathrm{eV}$ ) and di-vacancy $\left(\mathrm{V}_{2}\right)$ of different charging state (as =/with $E_{2} \sim 0.23 \mathrm{eV}$ and $0 /-$ with $E_{3} \sim 0.45 \mathrm{eV}$ ) defects.

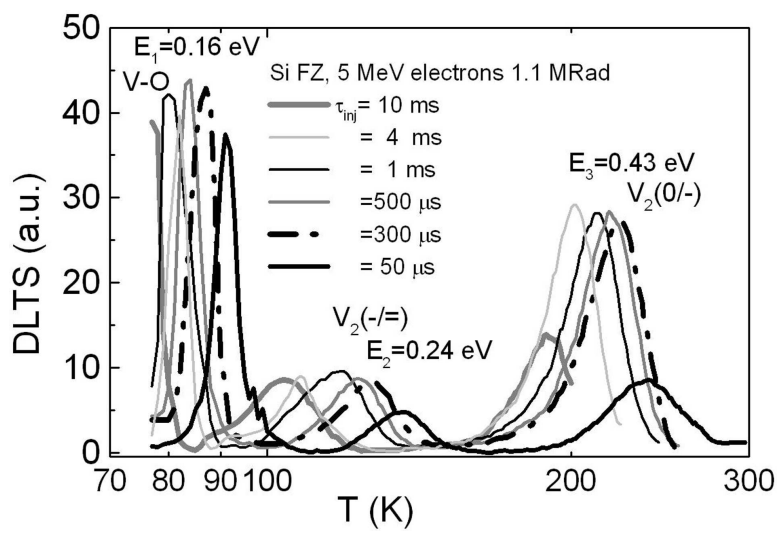

Fig. 3. Capacitance DLTS spectra in electron irradiated FZ Si diode.

DLTS peaks (Fig. 3) and indicate the different activation energy of the majority carrier trapping levels, namely, the $0.16,0.24$, and $0.43 \mathrm{eV}$. These traps are well-known $[2,6]$ as vacancy related centres and are denoted in Fig. 3 using widespread designations.

\section{Dose dependent generation lifetime variations}

Concentration $M$ of trapping centres has been examined by analysis of generation lifetime temperature variations measured using the capacitance DLTS. The dose dependent spectra variations obtained for commercial Si diodes are shown in Fig. 4. The vacancy attributed centres dominate within these spectra, while concentration of $\mathrm{V}-\mathrm{O}$ complexes prevails, similarly as in CERN detectors (Fig. 3). However, the DLTS band close to a peak ascribed to divacancy $\mathrm{V}_{2}(0 /-)$ becomes

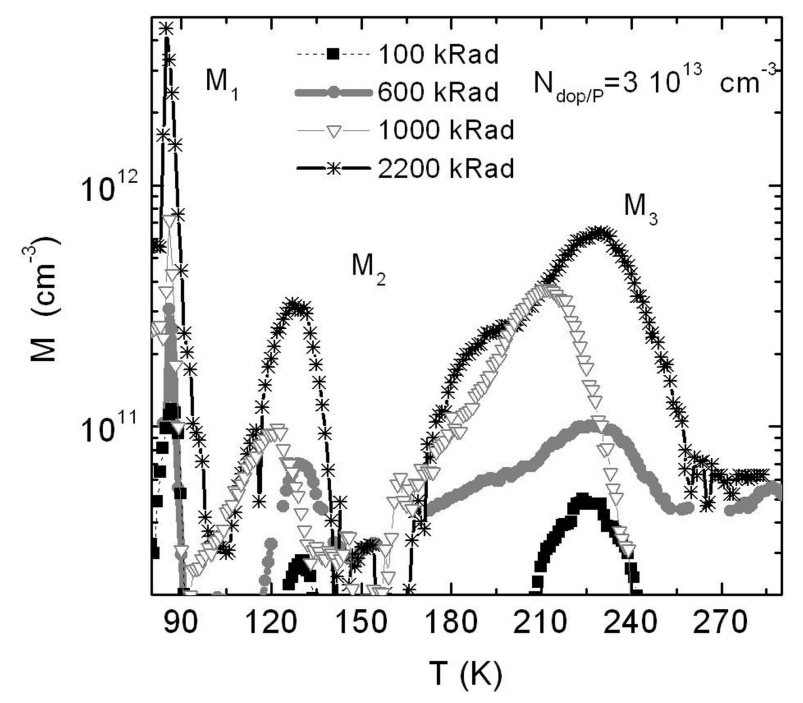

Fig. 4. Dose dependent variation of DLTS spectra in commercial diodes and estimated concentration of traps.

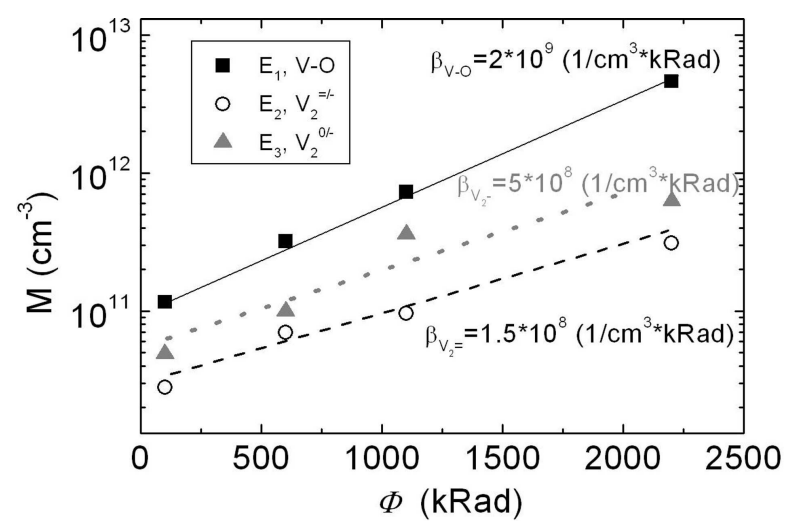

Fig. 5. Concentration of radiation induced traps as a function of dose $\Phi$ under $10 \mathrm{MeV}$ electron irradiation.

more complicated. This can be attributed to competition among centres ascribed to divacancy, vacancy cluster, and phosphorus-vacancy defects.

Variations of radiation induced traps as a function of $10 \mathrm{MeV}$ electron irradiation dose $\Phi$ are illustrated in Fig. 5. Nearly linear increase of $M$ with $\Phi$ can be clearly observed. This enables one to estimate a defect introduction rate for each trap as a slope in the $M$ versus $\Phi$ plot. Parameters of defect introduction rate allow estimation of concentration of species of the radiation induced defects within dose variations of industrial irradiations to manipulate the diode recovery characteristics.

\section{Conclusions}

The two-componential carrier decay transients have been revealed within temperature variations of excess carrier density relaxation in electron irradiated diodes. 
Examination of the excess carrier decay constituents have been employed to characterize the competing recombination and trapping centres. The vacancy ascribed defects dominate in the electron irradiated FZ Si material and mainly determine variations of the majority carrier trapping lifetime. Concentration of the centres ascribed to $\mathrm{V}_{2}$ and $\mathrm{V}-\mathrm{O}$ complexes increases linearly with irradiation dose. An agreement between characteristics of these centres measured by MW-PCT and DLTS are obtained.

\section{Acknowledgement}

This work was supported by the Lithuanian State Science and Studies Foundation.

\section{References}

[1] M. Moll, Radiation tolerant semiconductor sensors for tracking detectors, Nucl. Instrum. Methods A 565, 202-
211 (2006).

[2] J. Pintilie, Thermally stimulated current method; G. Kramberger, Charge trapping, in: Presentations at Workshop on Defect Analysis in Silicon Detectors, Hamburg, August 2006: http: / / wwwiexp. desy . de/seminare/defect. analysis.workshop. august. 2006 .html.

[3] E. Gaubas, J. Vaitkus, G. Niaura, J. Härkönen, E. Tuovinen, P. Luukka, and E. Fretwurst, Characterization of carrier recombination and trapping processes in proton irradiated silicon by microwave absorption transients, Nucl. Instrum. Methods A 546, 108-112 (2005).

[4] E. Gaubas, Transient absorption techniques for investigation of recombination properties in semiconductor materials, Lithuanian J. Phys. 43, 145-165 (2003).

[5] S.M. Ryvkin, Photoelectronic Effects in Semiconductors (Consulting Bureau, New York, 1964).

[6] M.-A. Trauwaert, Radiation and Impurity Related Deep Levels in Si, PhD thesis, IMEC-KUL, Leuven, 1995.

\title{
APŠVITOS DOZĖS NULEMTI KRŪVININKU REKOMBINACIJOS KITIMAI DIDELĖS ENERGIJOS ELEKTRONAIS ŠVITINTAME SILICYJE
}

\author{
E. Gaubas ${ }^{\mathrm{a}}$, A. Uleckas ${ }^{\mathrm{a}}$, J. Višniakov ${ }^{\mathrm{b}}$ \\ ${ }^{a}$ Vilniaus universiteto medžiagotyros ir taikomuju mokslu institutas, Vilnius, Lietuva \\ ${ }^{\mathrm{b}}$ Akcinè bendrove „Vilniaus Ventos puslaidininkiai“, Vilnius, Lietuva
}

\begin{abstract}
Santrauka
Nagrinėjami rekombinacijos būdingụjų dydžių kitimai Si dariniuose, keičiant apšvitos dozę bei tiriant defektu pasireiškimą zoninio lydymo būdu išauginto Si diodų dariniuose. Dariniai buvo apšvitinti 5-10 MeV energijos elektronu pluošteliu, keičiant apšvitos dozę 100-2000 kRad srityje. Rekombinacijos parametrai ištirti kombinuojant standartinę giliụjų lygmenų talpinę spektro-
\end{abstract}

skopiją bei mikrobangu sugerties relaksacijos kinetiku metodikas. Atskleista, kad defektai, aptikti giliụjų lygmenų talpinès spektroskopijos būdu, yra efektyvūs prilipimo centrai esant žemai temperatūrai, kai rekombinaciją lemia didesnio krūvininkų pagavimo skerspjūvio defektai. Sukalibravus gaudyklių koncentraciją, buvo ivertintos šių defektų sukūrimo spartos dozinès priklausomybès ir surasti defektu sudarymo spartos koeficientai. 